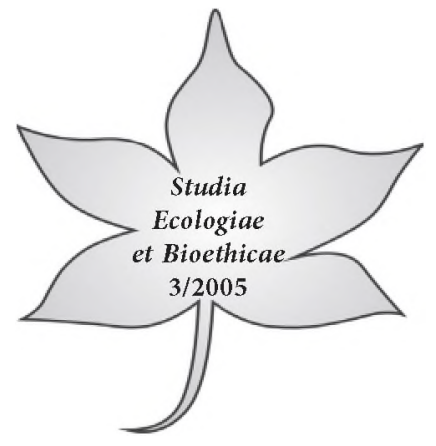

\title{
Rachunek sozologiczny instrumentem w polityce i ekonomii środowiskowej
}

\section{Wprowadzenie}

$Z$ dużym uproszczeniem można założyć: rachunek to określone działanie, które implikuje wynik. Ten dla ogólnego bilansu problemów jest korzystny lub niekorzystny.

W rachunku sozologicznym wynik to: zrównoważony rozwój lub jego brak, bo występuje klęska bądź kataklizm.

Powstaje pytanie co powoduje regres w rozwoju?

Niewątpliwie to straty ekologiczne, które są przedmiotem zainteresowania sozoekonomii.

W wystąpieniu zamierzamy zasygnalizować tylko niektóre aspekty nowej dyscypliny ekonomicznej, jaką jest ekonomia środowiskowa - sozoekonomia. Rozważania podjęte mają charakter ogólny i syntetyczny.

Na ukonstytuowanie się tej nowej dyscypliny z pogranicza sozologii i ekonomii miały wpływ analizy przyczyn i rozmiarów kryzysu ekologicznego, który odcisnął swe wyraźnie piętno na współczesnych społeczeństwach. Życie w nadmiernie zniszczonym środowisku jest bowiem przyczyną wielu chorób cywilizacyjnych, które przyczyniły się wydatnie to obniżenia jakości życia przeciętnego człowieka. Z drugiej strony ekonomiści zwrócili również uwagę, iż zdewastowane środowisko przyrodnicze powoduje duże straty ekonomiczne w gospodarce narodowej. Dotychczas bowiem ekonomiści nie uwzględniali w swych założeniach strat związanych ze zniszczoną przyrodą, w myśl hasła, że biznes i ekonomią nie idą w parze $z$ ekologią. Nic dziwnego, iż tak pojmowany tradycyjny paradygmat w ekonomii, niejako przyzwolił na szeroko zakrojone działania, które nie liczyły się z „dobrem” środowiska przyrodniczego i jego mieszkańców - a przede wszystkim człowieka.

Ekonomiści przypominają, iż pomijanie -na globalną skalę - w rachunku ekonomicznym tzw. strat ekologicznych może przyczynić się do poważnego wyeksploatowania środowiska, które przecież jest również dobrem. 
Dla miłośników przyrody, stanowi dobro bezcenne. Z punktu widzenia ekonomii to też wartość którą w przybliżeniu można oszacować.

Znane są przypadki, w których nadmiernie zdegradowane środowisko, wymagające natychmiastowej rekultywacji przynosiło olbrzymie straty finansowe dla gospodarki narodowej.

Nic więc dziwnego, że niektórzy politycy i ekonomiści zauważyli potrzebę uwzględniania strat związanych ze zniszczoną przyrodą w rachunku ekonomicznym. W naszych rozważaniach będziemy nazywali go rachunkiem sozologicznym.

Tak zrodziła się idea ekonomii proekologicznej - sozoekonomii, która posiada coraz bardziej znaczące miejsce w systemie ekorozwoju.

Dlatego uznaliśmy że zasadne jest przedstawienie ogólnej i zwięzłej charakterystyki idei ekorozwoju, która dała podłoże pod ugruntowanie się ekonomii środowiskowej. Następnie scharakteryzujemy ściśle z nią powiązaną strategię polityki ekologicznej i sozoekonomicznej. Konstatacje te posłużą nam za podłoże do nakreślenia kwestii ekonomicznych instrumentów ochrony środowiska, tzw. strat ekologicznych, które wchodzą w zakres rachunku sozologicznego.

\section{Ekorozwój celem dla polityki i ekonomii środowiskowej - sozoekonomii}

Człowiek skazany jest na ciągłe przekształcanie i ingerowanie w ekosystemy. Należy pamiętać, iż idea ekorozwoju wskazuje na konieczność takiego przeorientowania strategii rozwoju gospodarczego świata, aby nie powodować w przyrodzie nieodwracalnych zmian. Takie założenie przyświecało rozważaniom podejmowanym w kolejnych raportach Klubu Rzymskiego, mających na celu opracowanie tzw. modelu latynoamerykańskiego, związanego z próbą odpowiedzi na pytanie: W jaki sposób powinny być wykorzystane zasoby świata, aby optymalnie poprawić los każdego człowieka? ${ }^{1}$ Twórcy owych raportów odrzucili tradycyjnie rozumiany wzrost gospodarczy, „wyrażony powiększeniem produktu społecznego brutto per capita - jako miarę i przejaw wzrostu dobrobytu społecznego. Odrzucenie to wynika $z$ przesłanki, że wzrost gospodarczy oparty na dominacji przemysłu prowadzi do nadmiernego zużycia szeroko rozumianych zasobów przyrodniczych. ${ }^{2}$

Tradycyjnie wyznawanej wizji czy też teorii wzrostu gospodarczego i przedstawianej w raportach o szansach przetrwania ludzkości przeciwstawia się pojęcie ekorozwoju. Tak rozumiany zrównoważony rozwój zakłada optymalne wykorzystanie walorów środowiska przyrodniczego, zgodnie z zasadami jego naturalnego funkcjonowania, bez naruszania równowagi w ekosystemach.

Zarówno polityka ekologiczna, jak i ekonomia środowiskowa wypływają z zasad trwałego i zrównoważonego rozwoju: społecznego, gospodarczego, kul-

J. Bohdanowicz, Ku cywilizacji ekorozwoju, Gdańsk 1998, s.160.

S. Nahotko, Podstawy ekologicznego zarzadzania przedsiębiorstwem, Bydgoszcz 2002, s.55. 
turalnego będąc niezbędnym warunkiem ich funkcjonowania. To przede wszystkim od polityki państwa zależy, czy w kraju będą realizowane postulaty charakterystyczne dla idei ekorozwoju.

Jak zauważył B. Poskrobko, polityka ekologiczna: „jest to świadoma i celowa działalność władz różnych szczebli w odniesieniu do środowiska przyrodniczego. Polega ona na tworzeniu warunków do racjonalnego użytkowania zasobów i walorów środowiska, jego właściwej ochronie i umiejętnym kształtowaniu na podstawie zdobytej przez ludzkość wiedzy teoretycznej i praktycznej”3.

Częścią tak pojmowanej polityki ekologicznej jest polityka sozologiczna, która „obejmuje całokształt działań służących ochronie środowiska - w celu utrzymania stanu jakości i zasobów środowiska zgodnego z wymogami ekologicznymi"

Zaś celem nadrzędnym polityki ekologicznej jest „promocja zdrowia, czyli osiągnięcia takiego stanu jakości wszystkich komponentów środowiska, który nie będzie zagrażał ludzkiemu zdrowiu i życiu całej biosfery"s.

Naturalnie nie będzie efektywnej polityki ekologicznej bez urzeczywistnienia postulatów wypływających z ekonomii środowiskowej - sozoekonomii, która jest ściśle powiązana $\mathrm{z}$ sozologią. Bowiem ekonomia środowiskowa - sozoekonomia jest nauką „o ekonomicznych aspektach ochrony środowiska, szerzej - o ekonomicznych skutkach wynikających z naruszeń środowiska oraz o kosztach i ekonomicznych efektach działań ochronnych", dając w ten sposób „ekonomiczne uzasadnienie teoretycznym podstawom działalności ochronnej, ukazując ekonomiczne skutki ingerencji człowieka w układy przyrodnicze oraz ekonomiczne i społeczne skutki korzystania ze skażonego środowiska”. W tej młodej dyscyplinie naukowej sozologia jako nauka o ochronie przyrody, „umożliwia naukom ekonomicznym wartościowanie tych zasobów, kwantyfikowanie szkód i w rezultacie - strat ekonomicznych. Dopiero na tej podstawie można konstruować modele rachunku ekonomicznej efektywności ochrony środowiska oraz tworzyć mechanizmy oddziaływania ekonomicznego na użytkowników zasobów środowiska”.

Należy przy tym podkreślić, iż podstawową zasadą i instrumentem sozoekonomii jest uwzględnianie tzw. strat ekologicznych, które w dotychczasowym rachunku ekonomicznym na ogół były pomijane. W dłuższej perspektywie negatywnie odciskały swe piętno na gospodarce narodowej.

Można więc zaryzykować tezę, iż ekonomia środowiskowa wyewoluowała z klasycznej ekonomii, kładąc (w przeciwieństwie do tradycyjnej ekonomii) główny akcent na ujmowaniu w swych kalkulacjach szkód wyrządzonych przez ludzi środowisku przyrodniczemu.

B. Poskrobko, Zarządzanie środowiskiem, Warszawa 1998, s. 118.

4 B. Kryk, Polityka ekologiczna i sozologiczna a polityka ekonomiczna, (w:) Gospodarka a środowisko przyrodnicze. Pod red. T. Madeja, Szczecin 2002, s. 149.

Ibidem, s. 150

6 T. Madej, Ekologia, sozologia, sozoekonomia, (w:) Gospodarka a środowisko przyrodnicze, op. cit., s. 34 . 


\section{Straty ekologiczne w mikroekonomii i makroekonomii}

Zanim podejmiemy problem strat ekologicznych, jako instrument ekonomiczny i wskażemy jego miejsca w gospodarce narodowej, warto przybliżyć istotę tego terminu.

Truizmem jest stwierdzenie, iż korzystanie ze środowiska przynosi nie tylko zamierzone efekty społeczno - gospodarcze lecz i gwałtowne zmniejszanie się ilości zasobów. W efekcie doprowadza to do: zakłóceń w stanie równowagi ekologicznej i nieodwracalnych zmian w przyrodzie, wskutek nadmiernego jej zniszczenia.

W problematyce dotyczącej społeczno - gospodarczych skutków zanieczyszczenia środowiska wyróżnić można trzy podstawowe źródła zagrożeń?:

1. Geograficzno - demograficzne. Wtedy, gdy koncentracja działalności gospodarczej pociąga za sobą wzrost liczby ludności oraz nasila procesy urbanizacyjne.

2. Techniczno - ekonomiczne. Większość tego typu zagrożeń powstaje wskutek zagrożeń ze stosowania przestarzałych technologii, lub rozwiązań technicznych, które nie spełniają wymagań ochrony środowiska. Wśród czynników ekonomicznych wymienia się taką alokację zasobów, która w rachunku ekonomicznym nie umieszcza strat $\mathrm{z}$ tytułu zniszczonego środowiska.

3. Kulturowo - społeczne. Związane są one $\mathrm{z}$ rangą jaką ludzie przypisują potrzebie szanowania przyrody. Wynikają one z historycznie ukształtowanych norm kulturowych, hierarchii wartości, obyczajów.

W literaturze coraz częściej pojawia się termin „straty ekologiczne” na oznaczenie szkód, jakie człowiek wskutek swojej działalności wyrządził środowisku. Straty ekologiczne są ściśle powiązane z stratami ekonomicznymi.

Istnieją duze trudności w definiowaniu strat ekologicznych. Głównie natury metodologicznej i ekonomicznej. Do tej pory były pomijane w tradycyjnym rachunku ekonomicznym. Z przyczyn już wcześniej zasygnalizowanych istnieje konieczność poszerzenia tego rachunku, by uwzględniać wartość ekonomiczną naturalnego środowiska.

W takim ujęciu można przyjąć, iż straty ekologiczne - „to zmniejszone lub nieosiągnięte korzyści społeczne z tytułu użytkowania zasobów środowiska, wyrażające się obniżeniem bieżącego oraz przyszłego dobrobytu społecznego"s.

Problem, który w piśmiennictwie określany jest mianem strat ekologicznych ma już długą historię. Jak zauważył Leszek Trząski, znany jest co najmniej od połowy XIX wieku, gdy niektórzy przyrodnicy i ekonomiści zdali sobie sprawę, że zasoby przyrody mogą zostać poważnie naruszane (a nawet wyczerpane). Zmniejszanie się powierzchni lasów, gleb, wody i czystego powietrza jest realnym zagrożeniem, którego skutki można przeliczyć na pieniądze9 .

B. Skubiak, Ekonomiczne instrumenty ochrony środowiska, (w:) Gospodarka a środowisko przyrodnicze, op. cit., s. 181-182.

8 L. Trząski, Edukacja ekologiczna. Podręcznik, Katowice 2003, s. 207.

9 Ibidem. 
Jak podają źródła historyczne jeden z takich pierwszych przykładów strat ekologicznych w naszym kraju, został opisany w latach sześćdziesiątych XIX wieku. Król pruski Wilhelm I poszukiwał funduszy, które zgromadził w wyniku przetrzebienia pruskich lasów oraz wycięcia lasu sosnowego z Mierzei Wiślanej. Wskutek tej ostatniej operacji doprowadzono do zabagnienia mierzei czego następstwem było utrudnienie komunikacji między Elblągiem i Królewcem oraz dużych strat w rybołówstwie. Przez kilkadziesiąt następnych lat, bez efektu starano się z powrotem zalesić mierzeję ${ }^{10}$. Warto przytoczyć współczesny temu zdarzeniu komentarz: „Operacya (...) przyniosła wprawdzie królowi około 200000 talarów dochodu, lecz teraz dano by miliony, gdyby można odzyskać las"11.

L. Trząski zauważył, iż „Wiek XIX i XX przyniosły wiele dowodów na to, że wymierne straty ekologiczne pojawiają się praktycznie we wszystkich rodzajach ekosystemów i dotykają na co dzień wszystkich ludzi. Niestety, obecny system ekonomiczny świata oparty jest na krótkowzrocznej kalkulacji zysków i strat, nie uwzględniając tego problemu. Sytuacje podobne do wyżej opisanej ciągle jeszcze, niestety, mają miejsce, także w naszym kraju. Niewątpliwie ekonomia nie jest jeszcze gotowa do rozwiązania globalnych problemów środowiskowych"12.

Na podstawie literatury przedmiotu straty ekologiczne można sklasyfikować w następujące grupy ${ }^{13}$ :

1. Straty w środowisku przyrodniczym, powstałe wskutek:

- zniszczeń leśnych drzewostanów;

- zniszczeń w powierzchni rolniczej i w plonach;

- negatywnego wpływu nawozów sztucznych na strukturę gruntów;

- niepożądanych zmian we florze i faunie (ginięcie gatunków, wzrost chorób);

- zanieczyszczenia wód;

- zanieczyszczenia atmosfery.

2. Straty w produkcji, które wyrażają się:

- pogorszeniem jakości lasów oraz zmniejszeniem masy drzewnej;

- zmniejszenia plonów;

- wzrost kosztów produkcji;

- szybciej postępującą korozją maszyn i urządzeń technicznych;

- pogorszeniem jakości wody dla celów przemysłowych;

- zmniejszeniem lub wyczerpaniem bogactw naturalnych.

10 Ibidem.

11 K. Muller, Świat Roślinny. Tom I, Przygotowanie do podrózy, Drukarnia „Czas”, Kraków 1867, cyt. Za: T. Trząski, Edukacja ekologiczna, op. cit., s.207.

12 L. Trząski. Edukacja ekologiczna, op. cit., s.207.

13 Por. K. Leszczyński, Ekonomiczne problemy środowiska naturalnego, seria: Prace i Materiały Instytutu Rozwoju Gospodarczego, Warszawa 1978, nr 5, s.9-25; B.K. Prandecka, Nauki ekonomiczne a środowisko przyrodnicze, Warszawa 1991, s.122-123. 
3. Straty wynikające z pogarszania się warunków życia ludzkości:

- wzrost rodzaju chorób i liczby zachorowań;

- wzrost zagrożeń toksycznych dla zdrowia ludzi;

- wzrost negatywnego wpływu na genetyczny rozwój człowieka.

Wyżej nakreślona przeze nas typologia ma charakter ogólny i syntetyczny. Niewątpliwie szkody przyrodnicze prowadzą do strat w produkcji a także do wzrostu zachorowań, co znajduje następnie swoje odzwierciedlenie w gospodarce państwa. Naturalnie lista strat nie jest jednorodna. W piśmiennictwie naukowym występuje sporo różnych typologii. Ich główna myśl przejawia się w ujęciu strat ekologicznych, jako negatywnego zjawiska obniżającego poziomy: zaspokajania potrzeb społecznych i jakości życia, które „występują w formie ubytku, zniszczenia, bezproduktywnego zużycia zasobów naturalnych (szkody, straty bezpośrednie) oraz ubytku wartości materialnych, utraconych możliwości i utraconych korzyści (straty pośrednie)"14.

Po tej ogólnej charakterystyce warto przejść do ulokowania strat ekologicznych, jako instrumentu w rachunku ekonomicznym oraz ukazania ich roli w gospodarce narodowej.

W naszym kraju, do zwolenników włączenia do tradycyjnego rachunku ekonomicznego strat ekologicznych należy zaliczyć pionierskie prace A. Ginsberta - Geberta ${ }^{15}$ i jego zespołu. W 1976 roku zauważa on, iż przyczyną niestosowania w naszym kraju na szerszą skalę rachunku ekonomicznego w zakresie polityki ekologicznej i gospodarczej jest błędne utożsamianie interesów poszczególnych jednostek gospodarczych z interesem ogólnospołecznym ${ }^{16}$.

Według zespołu A. Ginsberta - Geberta, rachunek ekonomiczny w zakresie ochrony środowiska zawiera trzy elementy:

- „straty bezpośrednie i pośrednie,

- wydatki na odnowę (nakłady inwestycyjne i koszty eksploatacyjne urządzeń ochronnych),

- bezpośrednie i pośrednie efekty zastosowania środków ochrony"17.

Uważamy, iż warto nakreślić ulokowanie strat ekologicznych w rachunku ekonomicznym na poziomie mikro i makro.

W rachunku mikroekonomicznym ( $\mathrm{z}$ punktu widzenia przedsiębiorstwa, przedsiębiorcy) koszty ekonomiczne poniesione na rzecz środowiska przyrodniczego, zmniejszają w sposób bezpośredni zysk firmy. Między innymi dlatego, że przepisy skarbowe - tylko w wyjątkowych sytuacjach - pozwalają uwzględnić niektóre straty w rachunku kosztów. Dzięki czemu mogłyby zostać np. odpisane od podatku. Nie dziwi więc fakt, iż przedsiębiorcom po prostu nie opłaca się chronić

14 J. Famielec, Starty i korzyści ekologiczne w gospodarce narodowej, Warszawa - Karaków 1999, s. 66.

15 Por. Ekonomiczne aspekty ochrony środowiska. Pod red. A. Ginsberta - Geberta, Warszawa 1976.

16 J. Famielec, Starty i korzyści ekologiczne w gospodarce narodowej, op. cit., s. 65.

17 Ibidem. 
środowisko. Dlatego olbrzymia rola polepszenia tej sytuacji spoczywa na parlamentarzystach i politykach. Którzy zamiast akceptacji: podwyższania podatków (tzw. „ekopodatki”) i stosowania kar ekologicznych, mogliby uchwalić odpis wydatków poniesionych na ochronę środowiska, od podstawy opodatkowania.

Straty ekologiczne rozumiane są też w znacznie szerszym spektrum. Uwzględniają również - lub przede wszystkim - szkody ponoszone poza przedsiębiorstwem. Nie występujące w jego rachunkowości, a w rachunku makroekonomicznym określane mianem strat społecznych. Dotyczą one bowiem globalnego (w skali gospodarki narodowej) wzrostu kosztów funkcjonowania w zdegradowanym środowisku. Np. koszty oczyszczania i uzdatniania wody, rekultywacji zniszczonego terenu itp. Tak pojmowane koszty nie powinny być traktowane, jako element straty w rozumieniu ekonomicznym lecz jako miernik strat ekologicznych ${ }^{18}$.

W ujęciu ekonomicznym- ściśle makroekonomicznym, do strat ekologicznych zalicza się ${ }^{19}$ :

- „uszczuplenie majątku narodowego na skutek uszkodzenia lub zniszczenia różnego rodzaju dóbr ekonomicznych i społecznych,

- utratę określonych możliwości wytwórczych, spowodowanych zanieczyszczeniem lub przekształceniem różnych elementów środowiska,

- obciążenie dochodu narodowego zwiększonymi nakładami na różne procesy produkcyjne i konsumpcyjne,

- pogorszenie warunków zdrowotnych ludności." ${ }^{20}$.

Ekonomiści dążą do wyceny strat ekologicznych, bowiem przecież pośrednio hamują wzrost dochodu narodowego. Dotyczy to zwłaszcza obszarów produkcyjnych. Przykładowo wśród strat w produkcji można wyróżnić:

- „straty na skutek przyspieszonego niszczenia maszyn, urządzeń i obiektów infrastruktury technicznej,

- straty surowców i materiałów spowodowane emisją pyłów, gazów, odprowadzaniem ścieków i odpadów stałych,

- straty wynikające ze skażonych elementów środowiska (np. obniżenie jakości wyrobów w wyniku zużycia w procesach technologicznych zanieczyszczonej wody)"21. Natomiast straty w produkcji, których przyczyną jest zanieczyszczone powietrze atmosferyczne, podzielić można na następujące grupy:

- „przyspieszenie korozji (bezpośrednie koszty zanieczyszczeń korozyjnych, pośrednie koszty strat korozyjnych, koszty ochrony przed korozją),

18 Ibidem, s. 66-67.

19 To klasyczne ujęcie strat ekologicznych sformułował A. Symonowicz, który przeprowadził pierwszą kompleksową próbę wyceny strat ekologicznych w naszym kraju. Zob. A. Symonowicz, Straty z tytulu degradacji środowiska. Ich charakterystyka i próba szacunku, (w:) Ekonomiczne i socjologiczne problemy ochrony środowiska. Pod red. A. Ginsberta - Geberta, Wrocław 1988, s. 179.

20 J. Famielec, Starty i korzyści ekologiczne w gospodarce narodowej, op. cit., s. 67.

21 Ibidem, s. 69. 
- utrata surowców wskutek pylenia w procesie technologicznym oraz emisji pyłów lotnych i gazów,

- obniżenie stanu zdrowotnego pracowników przedsiębiorstw (zmniejszenie wydajności pracy, koszty utrzymania pracowników rezerwowych, dodatkowe koszty leczenia sanatoryjnego i wczasów, koszty przedwczesnej śmierci),

- straty w procesach technologicznych (w związku z wykorzystaniem zanieczyszczonego powietrza w procesie technologicznym oraz niemożności prowadzenia procesu technologicznego na danym terenie)"22.

Te dotychczasowe rozważania wskazują, iż dbanie o stan środowiska przyrodniczego stanowi pewnego rodzaju korzyść ekologiczną, która znajduje swe przełożenie na obszary ekonomii. W pewnym sensie, samo uniknięcie szkody jest korzyścią. Z drugiej jednak strony korzyść ekologiczna posiada również swój wymiar konkretny. W takim ujęciu można przyjąć, iż korzyści ekologiczne „obejmują wszelkie pozytywne skutki powstające w wyniku zaniechania działania (np. zrezygnowania z budowy uciążliwego zakładu), przedsięwzięć zapobiegających zanieczyszczaniu środowiska (np. instalacji filtrów, budowy oczyszczalni ścieków) bądź też przedsięwzięć likwidujących źródła zanieczyszczeń (np. wdrażanie technologii bezodpadowych)"23.

Do korzyści ekologicznych, zaliczyć można:

- „poprawę stanu zdrowotnego ludności,

- wzrost produktywności lasów,

- przyrost plonów w rolnictwie,

- wzrost czystości wód,

- wydłuzenie eksploatacji majątku trwałego,

- wolniejsze wyczerpywanie się zasobów surowców,

- mniejsze zapotrzebowanie na surowce i materiały,

- poprawę estetyki otoczenia,

- poprawę samopoczucia ludzi,

- większą trwałość zabytków kultury, itp."24.

Jak wyżej nadmieniliśmy ekonomiści dążą do szacowania, wyceny strat ekologicznych, które przecież obnizają wzrost dochodu narodowego. Jest to bardzo ważne zagadnienie, któremu chcemy poświęcić odrobinę miejsca poniżej.

\section{Wycena szkód ekologicznych w rachunku sozologicznym}

Na wstępie tego problemu warto ustosunkować się do sposobów szacowania szkód. Szacowanie szkód ekologicznych mimo, że dotyczy zjawisk już zaistniałych, jest przedmiotem wielu kontrowersji. Istnieje wiele elementów przyrodni-

22 Ibidem.

23 Ibidem, s. 72 .

24 Ibidem. 
czych, które nie mogą być przedmiotem obrotu rynkowego, a więc nie mają ceny rynkowej. Mimo tej trudności ekonomia w ciągu ostatnich kilkudziesięciu lat wypracowała metody, które można podzielić na: pośrednie i bezpośrednie ${ }^{25}$.

Do metod pośrednich zaliczamy techniki pomiaru, polegające na związaniu badanego dobra przyrodniczego z dobrem rynkowym. Za przykład posłużyć może wycena pięknego widoku, której przecież nie sposób bezpośrednio wyrazić w jednostkach pieniężnych. Jednakże cena rynkowa nieruchomości położonej w atrakcyjnym pod względem przyrodniczym miejscu, będzie większa od nieruchomości nie posiadającej takich walorów przyrodniczych. Ta technika pomiaru nazywana jest w ekonomii metodą cen hedonicznych ${ }^{26}$.

Odmianą takiego podejścia jest tzw. metoda płac hedonicznych. „Za jej pomocą możemy badać wartość ogólnych warunków środowiskowych, które sprawiają, że ludzie cenią sobie jedne regiony bardziej niż inne, chociaż płace w regionie atrakcyjniejszym będą niższe. Ten ubytek w rocznych dochodach pieniężnych jest miarą wartości nierynkowych, jakie, najwyraźniej, są w stanie zrekompensować mieszkańcom niższe płace"27.

W analogiczny sposób do wyżej opisanego, można wycenić wartość dóbr przyrody, które umożliwiają świadczenie usług rekreacyjnych i turystycznych. Podejście takie określa się w ekonomii metodą kosztu podróży, która „polega na zbadaniu, jakie wydatki ponoszą turyści, aby dotrzeć do miejsca uznanego za atrakcyjne. $W$ ten sposób szacuje się rekreacyjną wartość parków narodowych i innych dóbr, których nie można kupić”28.

Natomiast do bezpośrednich metod szacowania dóbr środowiskowych można zaliczyć metodę wyceny warunkowej. „Pytamy się w niej ludzi wprost o to, jaką wartość ma dla nich dobro środowiskowe"29. Przy pomocy odpowiednio przygotowanych ankiet, zadaje się respondentom pytanie, ile są gotowi zapłacić za dostarczenie konkretnego dobra. Naturalnie takie podejście obarczone jest zawsze błędem wynikającym z przeszacowania lub niedoszacowania badanego dobra.

Niestety w statystykach krajowych określających dochód narodowy opisują cych jakość życia, nie uwzględnia się rachunku sozologicznego. Czyli wartości utraconych zasobów przyrody, wskutek rabunkowej działalności człowieka. Jak zauważył L. Trząski prowadzi to do paradoksalnej sytuacji: „rabunkowa eksploatacja zasobów zwiększa dochód narodowy, natomiast niezbędne wydatki na ochronę środowiska zmniejszają go" ${ }^{30}$.

25 B. Skubiak, Ekonomiczne instrumenty ochrony środowiska, op. cit., s. 184.

26 Ibidem.

27 Ibidem.

28 Ibidem.

29 Ibidem, s. 185.

30 L. Trząski, Edukacja ekologiczna, op. cit., s. 211. 
We wcześniejszych partiach naszego tekstu usiłowaliśmy wykazać, iż takie podejście jest niesłuszne. Gdyż negatywne skutki tak pojmowanego wzrostu gospodarczego mogą doprowadzić do kryzysu ekologicznego, który jest również katastrofą ekonomiczną. Za przykład mogą posłużyć nam kraje rozwijające się.

Straty ekologiczne były w Polsce kilkakrotnie wyceniane ${ }^{31}$. Okazuje się, że w latach dziewięćdziesiątych XX wieku sytuacja w tym obszarze uległa poprawie. „W 1990 r. straty ekologiczne odpowiadały 8,1\% całkowitej produkcji w gospodarce narodowej oraz 15,2\% produktu krajowego brutto (PKB). W 1995 roku udział strat spadł o około $30 \%$ i wynosił 5,6\% całkowitej produkcji oraz $11,3 \%$ PKB. W tym samym czasie wydatki na ochronę środowiska były zdecydowanie mniejsze: 0,7\% PKB w 1990 r. i 1\% PKB w 1995 r."32.

\title{
Uwagi końcowe
}

Trend wzrostu wskaźników ekonomicznych może nas napawać optymizmem. Szkoda tylko, ze ta tendencja poprawy wynika głównie ze zmniejszania się produkcji przemysłowej. Ta spadła wskutek znacznego ograniczenia polskiego przemysłu, w okresie transformacji ustrojowej.

Mamy nadzieję, iż propagowanie idei ekorozwoju przyniesie ze sobą oczekiwany rozwój: gospodarczy, społeczny i kulturalny wraz z jednoczesnym poszanowaniem naturalnych zasobów środowiska przyrodniczego. Zaś rachunek sozologiczny spowoduje racjonalizację metod pracy ekonomistów, tak by ich instrumenty stały się bardziej efektywne z punktu widzenia optymalnego funkcjonowania ekonomii i polityki.

\section{Sociological calculation as a instrument in politics and environmental economy}

\author{
SUMMARY
}

This study show indicate idea of eco-development on environmental economy. Particularly marked interaction of connection between ecological losses and sociological calculation.

Layout for this study is as follow: eco-development as goal for politics and environmental economy, ecological losses in microeconomic and macroeconomic, evaluation in ecological harms in sociological calculation.

31 Wszystkich zainteresowanych szczegółowymi wycenami strat ekologicznych w polskiej gospodarce odsylamy do cytowanej pracy: J. Famielec, Straty i korzyści ekologiczne w gospodarce narodowej, Warszawa - Kraków 1999.

32 L. Trząski, Edukacja ekologiczna, op. cit., s. 209. 